\title{
State and Nation after the Failed Revolution
}

Chapter 9 examined how certain structures (and the intricacies of World War I) affected an event, the Finnish revolution. In this chapter the opposite question will be considered: that is, what effect this failed revolution had on certain structures. To answer this question the revolution will be viewed as part of a long-term development going beyond the event itself. The question is, what was the role of the abortive revolution in converting the grand duchy into an independent republic, and in particular what was its impact on the existing state structures and the process of national and class integration? The Russian revolution had provided the opportunity, the Finnish working-class movement had initiated a revolution that failed, and then the earlier nationally oriented culture provided the instruments for defining and analysing, in the White Finland of the 1920s and 1930s, what had taken place in 1917-18. How did the attempt at revolution modify the conditions governing national and class integration? What was to be the role of the entire national heritage in the newly independent country?

An answer to these questions requires both a state-making perspective and a conception of the specificity of the revolutionary situation in Finland. It also requires an analysis of Finnish fascism. Finland's interface position meant that a country with a Scandinavian social structure had confronted the collapse of a multinational empire, a situation unique in post-world-war history. ${ }^{1} \mathrm{~A}$ largely Eastern European fear of disorder and revolution was present, but dissimilarities in the social structure and state-making made it appear and function differently.

During the abortive revolution, a conception of the struggle emerged and was immediately consolidated in the dominant culture, where it took root and flourished well beyond World War II. The conflict was defined above all as a war for freedom or liberation (vapaussota), implying that it had primarily been a struggle for the liberation of Finland from Russian imperialism, which took

1 The closest case is Czechoslovakia, which, however, did not go through a revolution.

(C) KONINKLIJKE BRILL NV, LEIDEN, 2019 | DOI:10.1163/9789004386174_011

This is an open access chapter distributed under the terms of the CC BY-NC-ND $4_{R} 0$ license apuro $_{\text {- }} 9789004386174$ 
the form of Bolshevism after the autumn of 1917. In this light, Finnish revolutionaries were seen to be traitors who had conspired with the Russians to undo the newly won independence of their fatherland. The war thus acquired a certain internal character too, becoming, secondarily, a civil war (kansalaissota). ${ }^{2}$

In many ways this conception is understandable. The administrative Russification in the previous years had generated resentment, and fear of undisciplined Russian troops had grown among the bourgeois groups in 1917. A revolutionary Finland could hardly have escaped some sort of dependence on Soviet Russia. Also, when the Communist party of Finland was founded in Moscow in 1918, it was run by leaders of the failed revolution. But far more important were, first, the character and role of the national culture and, second, the specifically Finnish characteristics of the revolutionary situation.

As stated above, no signs of dissolution were discernible within the dominant classes prior to the outbreak of the revolution. No major conflicts of interest existed, and a far-reaching consensus about national integration prevailed. Only a few decades earlier, the intellectuals had formulated somewhat varying versions of nationalism as a civic religion for the emerging Finnish state, and the fundamentals of this nationalism were accepted fairly unanimously. Also, the Finnish educated class had become a bureaucratic intelligentsia: it participated actively in the construction of the state, and the university elite played a central role in politics and the bureaucracy. ${ }^{3}$ This distinguishes Finnish intellectuals radically from, say, their French counterparts under the ancien régime or the unemployed intellectuals in various pre-independence colonial countries. ${ }^{4}$ In Finland, because no powerful section of the elite was decisively outside the state bureaucracy, the variety of intra-elite conflicts that is apparently a key precondition for the emergence of a revolutionary situation did not exist. ${ }^{5}$ As to the socialist intellectuals, they were a tiny group, their revolutionary conceptions were quite vague, and they were nationalists who had actively propounded political democracy and Finnish independence since the spring of 1917 .

A tradition that provided few means for handling class conflict thus prevailed in the intellectual culture. It was this intellectual and emotional struc-

2 An example, as well as a prominent codification, of this view can be found in The Memoirs of Marshal Mannerheim (1953, chaps. 6 and 7). See also Ketonen 1983, pp. 23-4, 30-4.

3 Rommi 1964, pp. 129-30; Klinge 1970, p. 26.

4 These intellectuals were not only critical of the prevailing order but also isolated from political decision making. The classical analysis of France is Tocqueville's The Old Regime and the French Revolution.

5 Goldstone 1982, pp. 194-7. 
ture that, in 1917-18, was suddenly and without premonition forced to react to and try to comprehend a revolutionary situation. The revolution was a horrible and nearly total surprise for the entire intellectual culture - as it was a surprise for the great majority of the revolutionaries themselves. A revolution occurred which was not preceded by long-term fissures within the dominant classes or by deterioration of the social and economic fabric in the world war, but which was a result largely of Finland's dependence on Russia for the maintenance of order. The solidarity of the people with the 'national' educated class, one of the basic tenets of the national ideology, seemed to break down all at once, and in a manner that could not have been reasonably expected given the nature of the previous Social Democratic challenge. ${ }^{6}$

The 'catastrophe' was interpreted, naturally enough, within the framework of the national ideology. Although the White military and political leaders as well as the White press were fully aware of the domestic character of the war from the outset, ${ }^{7}$ this conception did not take root. Immediately after the war broke out, a notion emerged that portrayed it as a struggle for the 'fatherland', for 'freedom', and for the 'whole Finnish people', against 'dark forces', 'criminal bands', and 'chaos.8 The Russians fit into this perspective admirably. The existing distrust toward them grew to totally new - racialist - proportions. The Finnish challenge to state authority was seen as resulting from the 'Russian plague' that had 'infected' the revolutionaries. ${ }^{9}$ Soon this conception evolved into the idea of a 'war for freedom' against Bolshevik Russia. Although initially formulated in the Activist propaganda meant for both the foreign and the domestic audience, ${ }^{10}$ the conception corresponded first and foremost to longrun trends in the prevailing culture, and not merely to the short-run character of the revolutionary situation. This notion explained in the simplest possible way the seemingly inconceivable revolt of a part of the people 'against itself'. In the nationalist perspective, seeing the armed conflict as a war for freedom certainly made more sense than any alternative interpretation: it preserved the idea of a single national entity, precious for the national ideology, by projecting

6 There were exceptions, mainly in the Swedish-speaking intelligentsia. Some of its representatives had adopted racial ideas from Western Europe or even had visions, in the prerevolutionary years, of a socialist holocaust. See Hyvämäki 1971, pp. 33-49, 58-9; and Klinge 1972, pp. 51-3, 96, 105-8. Another matter concerned the fissures left by the 1905 revolution in the idealised conception of the people. See below, n. 12. T. Manninen 1982, pp. 30-2, 73-5, 83-8, 141-7. The Ostrobothnian newspapers were a partial exception (ibid., pp. 135-40).

8 Ibid., pp. 154-64; M.-L. Kunnas 1976, p. 52. See also Paavolainen 1966-7, 2: 27-39.

9 T. Manninen 1982, pp. 164-79; Upton 198o, pp. 311-13; Kena 1979, pp. 83-9.

10 T. Manninen 1982, pp. 95-7. 
the cause of revolution outside the nation. It minimised Finnish participation in the conflict, thus concealing its class character.

In this perspective the Finnish Reds are seen as 'misled' - misled by the Russians or, more commonly, by their own leaders who were infected by the Bolsheviks. ${ }^{11}$ A related view asserts that they were easily misled because of a specific purported national character. In this view, Finns are sullen and suspicious but, if angered, totally uncontrollable, insidious, and ready to stab their compatriots in the back. The view had older roots, notably in the fissures left in the idealised conception of the people by the 1905 revolution. But now it seemed enormously more persuasive than ever before. ${ }^{12}$ It was as if Russian incitement had released the dark forces hiding in the Finnish soul, causing some Finns to join forces with the foreign enemy.

This is obviously a specifically Finnish version of the volcanic model of revolution - which, as Rod Aya says, is apparently the most persistent (and persistently misleading) way of seeing the revolutionary process..$^{13}$ But although the conception does not adequately explain the Finnish revolution, seeing the revolutionaries as misled may still catch something important. F.E. Sillanpää's masterly novel Meek Heritage expresses this beautifully. Written in the summer and fall of 1918 and published in 1919, this book was profoundly sympathetic to the defeated, whom it portrayed as being at the mercy of greater forces. The leading character is a cottager executed by the victorious Whites. This naive and passive man, having no idea of the political implications of his modest services to the local administration, is finally shot due to a misunderstanding, and thus is 'drawn into the swelling turmoil of the times'. ${ }^{14} \mathrm{He}$ is an 'unconscious' victim of a revolutionary process that is totally beyond his comprehension. Certainly there are people like him in all major uprisings, but the characterisation captures something essential in the Finnish revolution. The revolutionaries were really drawn into revolution, and when it began they had no clear idea what to do with the power they obtained. Among the masses, the confusion, lack of enthusiasm, and irresolution were at least as grave as among the leaders. In a word, the Finnish revolution was underdetermined: there were no deep endemic grievances among the masses that would have made them complete the destruction of the old order spontaneously. ${ }^{15}$ Sillanpää's novel may be seen

\footnotetext{
11 See ibid., pp. 178-9; M.-L. Kunnas 1976, p. 171.

12 Klinge 1972, pp. 105, 108-10; M.-L. Kunnas 1976, pp. 65, 102, 108-9; Hamalainen 1978, pp. 9597, 121-2; Sarajas 1962, pp. 135-8o.

13 Aya 1979, p. 5 o.

14 Sillanpää 1938, p. 222.

15 Certainly the action of the Finnish masses was very far from the spontaneous and autono-
} 
as characterising a revolution whose participants were seriously at a loss about how to use the power they had.

In accounting for the White terror, the character of the revolutionary situation and of the dominant culture also appear important. It is true, of course, that bloody repression has frequently accompanied the crushing of revolutions and other upheavals. But the fact that the revolutionary challenge remained incomprehensible and even insulting to the victors may explain some of the large-scale and summary killing (and also the continuous massacre of captured Russians).${ }^{16}$ Ilmari Kianto, the author of a famous novel dealing with the $1906-$ 1907 political mobilisation in the eastern backwoods (see p. 213), was not alone when he wrote toward the end of the war: 'Is it not prejudice or downright short-sightedness to leave unpunished precisely those who, simply by adding to their families, strengthen the enemy force? Would it not be a correct tactic to take some stated percentage of the second sex of the enemy?' He went on to say that those who carried out such a work would be 'creating a great new Finland, the vigilant representatives of the fatherland and high idealism. ${ }^{17}$

\section{The Persistence of the Volcanic Model of the Finnish Revolution}

The process of disengagement from the original 'volcanic' model of the Finnish revolution has been slow and painful, reflecting the continuing difficulty of the dominant culture to come to grips with the conflict. Today, although the original model has practically no advocates, its long shadow may still be discerned in the historiography (see p. 176). ${ }^{18}$ For decades the academic community was incapable of dealing with the encounter, and it is thus perhaps no wonder that literary works have been instrumental in reinterpreting the revolution and making it comprehensible for the dominant culture. ${ }^{19}$ Sillanpää's novel caught

mous violence James C. Scott argues is characteristic of the peasant movements that have instigated rebellions or contributed to the rise of revolutionary situations. See Scott 1976, pp. 193-203; and Scott 1977, p. 243.

16 See Upton 1980, pp. 311-13.

17 Cited in Upton 198o, p. 314. See also T. Manninen 1982, pp. 157-61.

18 The conception of the war as a combination of an outburst, an insurrection of the misled against the legal government, and a war for liberation from Russia was widely accepted among historians as late as the early 196os (see Stormbom 1963, pp. 207-15). Today historians still may portray the revolution, in the last analysis, as a challenge to 'legal government' (Jokipii 1981, p. 48) or to 'lawfully elected government' (O. Manninen 1975, p. 471; see also O. Manninen 1978, p. 229). This perspective is understandable given that the challengers lost, but it does not seem helpful in analysing a social conflict.

This is perhaps particularly true of the period before the 1950s, when the most percept- 
something essential long before any serious professional study. ${ }^{20}$ It also exerted some influence, even though it could not really breach the bourgeois hegemony of the time. ${ }^{21}$ Significantly, the definite fall of the original volcanic model was effected - four decades later - by another literary work, the second volume of Väinö Linna's great three-volume novel Here Underneath the North Star (1960). In this fresco of the year 1918 in a south-western agrarian community with a large crofter population, the conflict is crystallised in the vicissitudes of a crofter's son, who is an active member of the local workers' association, a Red Guard leader, and finally one of the tens of thousands of prisoners in the White camps.

This work so changed the atmosphere that the academic historians of the 1960s and the 1970s were encouraged to study seriously various aspects of the conflict. Linna's book was well grounded in historical fact and consciously 'sociological. ${ }^{22}$ Most important was his portrayal of the revolutionaries, not as misled or misbehaved, but as sensible and responsible people acting reasonably in their own interest. In the novel this characterisation added forcefully to the tragedy of the conflict and served as a distinct departure from the mainstream of earlier thinking. But Linna also saw the outbreak of the revolution as a reaction to unbearable circumstances, a release, made possible by the two subsequent revolutions in Russia, of the forces that had been blocked during the previous period. ${ }^{23}$ This perspective seems quite natural in a novel that details the behaviour and motives of individual human beings in a social microcosm. And indeed, there were grievances among the landless and the crofters, grievances that certainly came into the open in the revolution. But as noted above, this view, when seen from a larger historical perspective, fails to take into account the institutional context and therefore does not permit an adequate assessment of the overall significance of the 'release of tensions'. In the absence of an army and a police force, even comparatively minor grievances may eventually grow into overpowering claims. Consequently, Linna's interpretation, powerful as it was, did not cause historians and other students to question the very foundations of the volcanic view of the Finnish revolution.

ive analyses of the societal conflicts in twentieth-century Finland were made by writers rather than historians or social scientists. Sillanpää is only one example.

21 Rajala 1983, pp. 207-9, 212-14; Paavolainen 1966-1967, 2: 396-7.

22 Stormbom 1963, pp. 230, 271-2.

23 See also ibid., pp. 196, 204. 


\section{On the State, the Nation, and Class Balance}

After the revolution was crushed, the class balance in the country changed radically. The Communist party was, naturally enough, declared illegal, and there was no question of the Social Democratic movement acting in a framework similar to the one that prevailed between 1907 and 1917. The most eloquent indication of bourgeois domination was the position of the Civil Guard, which after the war was instituted as a nationwide organisation and maintained over and above the regular army, allegedly to secure the country against external and internal threats, ${ }^{24}$ and from which the Social Democrats were excluded.

Nevertheless, Finland experienced greater institutional continuity in state structures than practically any other inter-war Eastern or East-Central European state. A new independent state, it had a constitution and a political party system closely linked with pre-World War I developments, even though its preservation had been guaranteed by Entente pressure. The republican constitution, confirmed in 1919, had been prepared for the most part in late 1917 in keeping with the constitutional tradition, and it helped to fulfil the bourgeois objective of a 'strong governmental power'. The highest executive, the president, had substantially more prerogatives than in most other contemporary parliamentary political systems. ${ }^{25}$ Nothing strange was seen in linking the Civil Guard with the state machinery and in giving it considerable autonomy in internal matters.

In the inter-war bourgeois perspective, the war was only a tragic interlude in the unfolding of the nation. It was from this perspective that the victors attempted to reconstruct the broken national integration, to re-create an inter-class community bringing all the Finns together.

Efforts to create a strong national Gemeinschaft predominated on the right. The inspiration came from Fennomania, which was modified in light of prevailing conditions. Peasant values were revived, and a Finland united in culture - a 'national entity' - was to be built up and fortified against internal and external threats. Much more than ever before, Fennoman ideas were used to inculcate a civic religion for the state, and now strict ideological conformity was required. For example, the ideal world revealed in native folk poetry (particularly the $\mathrm{Ka}$ levala), so central for the national ideology, was reinterpreted to correspond to

24 See Tervasmäki 1964, pp. 61-71. On the intertwining of internal and external threats in the postwar period, see Ahti 1984b.

25 Lindman 1968, pp. 331-43, 369-72; Jyränki 1978, pp. 19-21, 24-47. There was a marked resemblance between the Finnish and the new German constitution. 
the claim for a rigorous martial unity, both outward and inward. ${ }^{26}$ As in other upper classes threatened by political upheavals, moral regeneration and the inculcation of moral virtues were seen to be central, and the church gained much in importance among the Whites. ${ }^{27}$ Politically the conception was represented by the National Coalition party, formed in 1919 from the monarchist majority of the (Old) Finnish party and the monarchist minority of the Young Finns, and largely supported by the Finnish-speaking wealthy landowners, the industrial and commercial elite, the higher bureaucracy, the military, and the clergy. In the 1920s, this party was the staunchest opponent of the 'unnational' working-class movement.

But another view of national integration emerged, stressing a certain degree of conciliation with the working class. Politically its proponents belonged to the liberal Progressive party, made up mainly of former Young Finns, and to the Agrarian Union, which in 1919 became a large party. The sixteen parliamentary seats the Agrarians had in 1916 grew in 1919 to forty-two, and in the 1920 s they became the largest bourgeois party (Table 11). During the early populist period after 1905, the Agrarians, feeling affinity for the nineteenth-century national movement, had considered it their task to be the revival and further development of that movement's democratic traditions. In the post-1918 situation, then, they presented the agrarian-national ideology, with the peasants as its foundation, as the only programme capable of reconciling the two main challengers of the war. A far-reaching agrarian reform, making landowners of the crofters and many cottagers, was implemented, largely because of pressure from the Agrarians. Plans for land reform had been prepared before the outbreak of the revolution, but now it was explicitly presented as a way of fortifying the nation and protecting it from further upheavals. For rehabilitating the rebels the Agrarians and the Progressivists envisioned amnesties and sociopolitical reforms. ${ }^{28}$

The distinction between the two views of national integration is reminiscent of the difference between the conservative ideology prevalent among the agrarian upper classes of Central and East-Central Europe and the populist or peasantist agrarian ideology found in the same areas. In the inter-war period there was a corresponding difference between the authoritarian and fascist ideologies. ${ }^{29}$ But although this distinction may be reasonably applied to Finland, it was of less importance there than elsewhere. What seems char-

\footnotetext{
26 See the detailed study of William A. Wilson (1976, esp. pp. 103, 107-11, 115-72).

27 Kena 1979, pp. 66-73; Alapuro 1973a, pp. 37-8.

28 For more detail, see Alapuro 1973a, pp. 24-6, 39-40; Kettunen 1979, pp. 284-94.

29 Ionescu 1969, pp. 99-19; Moore 1966, pp. 448-52; Fischer-Galati 198 o.
} 
TABLE 11 Distribution of seats in Parliament won in selected Finnish general elections, 1919-1933

\begin{tabular}{lccccc}
\hline Parties & $\mathbf{1 9 1 9}$ & $\mathbf{1 9 2 7}$ & $\mathbf{1 9 2 9}$ & $\mathbf{1 9 3}$ & $\mathbf{1 9 3 3}$ \\
\hline Social Democratic party & 80 & 60 & 59 & 66 & 78 \\
Socialist Workers' party & - & 20 & 23 & - & - \\
Agrarian Union & 42 & 52 & 60 & 59 & 53 \\
National Coalition party & 28 & 34 & 28 & 42 & 18 \\
People's Patriotic Movement & - & - & - & - & 14 \\
National Progress party & 26 & 10 & 7 & 11 & 11 \\
Swedish People's party & 22 & 24 & 23 & 21 & 21 \\
Others & 2 & 0 & 0 & 1 & 5 \\
Total & 200 & 200 & 200 & 200 & 200 \\
National turnout & $67.1 \%$ & $55.8 \%$ & $55.6 \%$ & $65.9 \%$ & $62.2 \%$ \\
\hline
\end{tabular}

a Communists and left-wing socialists.

SOURCES: ÉLECTIONS POUR LA DIÈTE EN 1919 1920, 27; ÉLECTIONS POUR LA DIÈTE EN 1929 1930, 25; ÉLECTIONS AU PARLEMENT DE FINLANDE EN 1933 1934, 7, 28

acteristic, rather, is a more-or-less united political culture - arguably a more unified bourgeois hegemony than in other countries influenced by the collapse of a multinational empire. A relatively united nationalistic culture had arisen by the first decades of the twentieth century, and it was solidified by the revolutionary experience and concomitant fear of a new Soviet state. The character of the landed class provided a solid basis for such unity. No clear-cut lines differentiated the wealthy peasants from the less prosperous ones, and when the Agrarians won over conservative-voting farmers in the 1920s, the party's populist image was obliterated, showing that no wide gap separated the two nationalist programmes. Both exalted the independent peasantry and peasant virtues.

The most revealing sign of the bourgeois consensus is certainly the Civil Guard. Unlike other bourgeois paramilitary organisations in inter-war Europe, the Guard was unanimously supported by all bourgeois parties, whether Finnish or Swedish. Its potential in a crisis can be seen from the fact that between 80,000 and 100,000 armed men served in the Civil Guard, as compared with some 25 ,000 to 30 ,000 in the army.

Another feature of the consensus is the overwhelming domination of a single organisation, the nationalist Academic Karelia Society (AKs), among the Finnish-speaking students. No other student movement could seriously compete with this group, and both nationalist views on integration, with some 
degree of tension between them, flourished in the AKs. True, the students campaigned against the use of Swedish by the upper strata and thereby irritated the bourgeois front, but in this effort they gradually became isolated. Even the Agrarians followed them only half-heartedly, not to speak of the Coalition party. ${ }^{30}$ Moreover, the position of the Swedish language was guaranteed in both the constitution and language acts in a manner satisfactory to the Swedishspeakers.

Equally important for the political atmosphere was the attitude of the working-class movement. The Social Democrats were allowed to act, but within limits set by the dominant bourgeoisie. The very existence of the Civil Guard defined what was 'reasonable' political activity. The Social Democrats accepted these basic conditions and backed the centrist line, avoiding any encounters that would have brought the Centre closer to the right. They defended and worked for the consolidation of representative political structures, following a consistent policy of 'class peace'. Significantly, in 1919 the constitution of the new, and independent, republic had granted the Social Democrats access to the polity, and not only at the national level but now also at the local level. ${ }^{31}$

Social Democratic compliance may be seen most concretely in the party's overwhelming concentration on political activity. This was, of course, consistent with the movement's earlier orientation, and therefore it is no surprise that the Social Democrats suffered a loss of key trade union positions to the Communists, who for their part had great difficulties in the political arena (see Table 11). Basically, however, the limits to the Socialists' trade union activity were imposed by the existing order. In inter-war Finland employers had no need to accept collective agreements in the labour market, and they never did. A strike-breaking organisation was active and effective throughout the 1920s. Individual voting acts were recognised, but collective action in the labour market was not. The Social Democrats' role in labour struggles thus remained minor, and ultimately, in 1929-30, they founded a new, purely Social Democratic trade union organisations. ${ }^{32}$

\footnotetext{
$30 \quad$ Rintala 1972; Alapuro 1973b, pp. 116-19, 124-7.

31 Kettunen 1979, pp. 328-51; Rintala 1969, pp. 55-6, 63-4 (the term class peace is from Rintala); Kettunen 1980a, pp. 131-43.

32 Kettunen 1979, pp. 154-6, 203-17, 279, 353-75, 412-13, 465-85. The Social Democrats formed a minority government in 1926. Its policies were far from socialist, and the Communists found no difficulty in attacking it. Interestingly, however, it was widely supported by the workers; what counted were not real achievements or the lack of them but the apparent recognition of a certain decency in the working class, reflected in the fact that its party had been accepted as a governmental party (Kettunen 1979, pp. 323-6, 343).
} 
The party's active involvement in parliamentary action by no means precluded the emergence of a 'camp mentality' among the workers: political and economic second-class citizenship was accompanied by cultural isolation. This isolation was reflected in an organisational network parallel to the bourgeois one. In the 1920s the workers not only voted for their own parties, but they also played, read, sung, participated in sports, shopped, and deposited their savings primarily in their own organisations and enterprises. The deep and pervasive concentration of popular activities around the workers' halls on the one hand and the civil guard halls on the other, so characteristic of local life in this period, reflects this polarisation better than anything else. The workers also definitely drew away from the church's sphere of influence. ${ }^{33}$

All in all, despite the revolution and its suppression, Finland had preserved the political system instituted in 1906, fortified now with a domestic president and a government. The Social Democrats could act, and were willing to act, within the prevailing system, and on the bourgeois side the only distinctively anti-parliamentary group, with roots in the counterrevolution of 1918-19, was quite small. Political consensus on fundamental questions ran from the Agrarians all the way through most of the right. In other words, the reactionary tendency was of little importance. This unanimity meant, however, that the entire bourgeois front was strongly anti-socialist - thanks to the fact that its ideological point of departure was a national heritage from which the working class was cut off and into which the traumatic experience of 1917-18 had been incorporated.

The Lapua Movement, 1930-2

The post-revolutionary quest for national integration climaxed in a Finnish variant of fascism, which, as in many other European countries, gained a real foothold during the Great Depression. The so-called Lapua movement greatly affected politics and nearly dominated the country in 1930, more than a decade after the abortive revolution. It was nationalist and anti-Russian in the extreme, held the party-based political system in contempt, succeeded in having all public activities by Communists - understood in a very diffuse sense - banned, and watched over the final disintegration of the trade union movement. After crushing the Communists, the movement attacked the Social Democrats, envi-

33 Suonoja 1968, pp. 59-6o; Kena 1979, pp. 103-4, 121-3; Hentilä 1982, pp. 68, 7o, 81, 83; Seppänen 1972, pp. 165-7, 171; Kettunen 1984, p. 38. 
sioning a reduction of political rights that would guarantee bourgeois supremacy in politics. At times, a seizure of power was not out of the question; the most serious threat appears to have been in the summer of $1930 .{ }^{34}$ In 1932, the movement attempted a coup d' état. Its failure led to the foundation of a political party, the People's Patriotic Movement, which held from eight to fourteen parliamentary seats from 1933 until World War II (see Table 11).

The Communists had succeeded in maintaining a presence in parliament and local politics under various labels throughout most of the 1920 (Table 11), and in the late 1920 s real and putative Communist activity led to a number of strikes. Meanwhile, the bourgeois parties were able to form only weak minority governments, demonstrating the deficiencies of the parliamentary system. In these ominous conditions, reminiscent of other pre-fascist situations, the Lapua movement emerged at the end of 1929, with anti-communist riots serving as its starting signal. ${ }^{35}$ The movement received its strongest immediate support from the Coalition party, but it found considerable sympathy in the political centre as well. From the end of 1929, the government, composed mainly of Agrarians, gave in to the Lapua movement constantly. Communists and those considered to be Communists were denied the freedom to form associations, and the government suppressed their publications after riots and other forms of pressure. In the summer and early autumn a fairly organised wave of terrorist acts, notably abductions, was undertaken, in which the police connived. The terrorists were civil guards, but as an organisation the Civil Guard itself stood aloof. Three people were killed. The total number of abductions and assaults rose to 254, with four-fifths of the victims being Communists (actual or alleged), the rest being Social Democrats. Among those abducted were members of local government bodies, party branches, public agencies, trade unions, newspaper staffs, candidates for and members of Parliament (including the deputy speaker), and even the country's first president. ${ }^{36}$

Through abductions and other pressure, the movement forced the replacement of the centrist government by a definitely rightist one in early July 1930, backing Svinhufvud as the new prime minister. Although he had been compelled to step aside in 1918, Svinhufvud nonetheless had enormous prestige as a symbol of victorious White Finland. He offered representatives of the Lapua movement portfolios in the government, but because of internal dissension its members refused. The cabinet arranged for the arrest of the Communist

34 Hyvämäki 1977, p. 135; Siltala 1985, p. 498.

35 Actually, at that time the Communist party was nearly paralysed.

36 Siltala 1985 , pt. 1, and pp. 319-33, 357-67; Rintala 1962, pp. 167, 174-5. 
deputies, and all organised activity considered to be Communist was systematically put down. These measures were later confirmed with anti-Communist laws, which were effected by ensuring a sufficiently large non-socialist majority in Parliament through new elections, held under heavy pressure from the Lapua movement. Communists and related groups were hindered in running for office. ${ }^{37}$

The culmination of this activity was reached in the pre-election period. In July 1930, 12,000 Lapua movement members, mainly farmers, marched on the capital with their demands, recalling the Whites' victory parade in $1918 .^{38}$ The Peasants' March, as it was called, was carried out under the auspices of the Civil Guard, and Mannerheim as well as Prime Minister Svinhufvud and the president, the Agrarian Relander, were present at the main demonstration.

After the elections and confirmation of the anti-Communist laws, conservative support for the movement began to decline. The movement turned against the Social Democrats, calling for the extermination of every form of 'Marxism' in Finland. Although the movement had elevated Svinhufvud to the premiership as its own man, friction arose almost immediately after he assumed office. More distinct differences came to the surface in 1931 when Svinhufvud was elected president as a Coalition party candidate. The movement, to be sure, strongly supported him during the electoral campaign; it is also evident that the Civil Guard exercised pressure on members of the electoral college, and especially on the Agrarian electors, before the final vote. ${ }^{39}$

The differences became irreconcilable, however, at the time of the so-called Mäntsälä revolt, which led to the dissolution of the Lapua movement, at least in its original form. In the spring of 1932 the movement's leadership lent its support to a revolt in Mäntsälä, a community near the capital, attempting to secure the backing of the civil guards there. ${ }^{40}$ Among its demands was a call for the government's resignation and the establishment of a new, 'apolitical', 'patriotic' government. The aim was apparently to make Mannerheim head of state and to appoint a conservative industrialist - a former general and a member of the Lapua movement leadership - as prime minister. Numerous Coalition party leaders, a large portion of the Civil Guard leadership, including its commander, and many officers of the armed forces rallied to the movement's cause.

Thanks to resistance personified notably by Svinhufvud and the commander in chief of the army, the Lapua movement failed, however. At the crucial

$37 \quad$ Siltala 1985, pp. 112, 144-86.

38 Siltala 1985, p. 122.

39 Rintala 1962, pp. 177, 189; Kalela 1976, p. 117.

40 On the Mäntsälä revolt, see Rintala 1962, pp. 191-4. 
moment it could not mobilise the rank and file of the local civil guards, in which rural elements constituted a clear majority; the commercial and industrial elite had withdrawn much of its initial support for the movement; and the non-conservative bourgeois parties and the Social Democrats had, of course, increasingly opposed the movement since late $1930 .{ }^{41}$

The mass following of the movement was centred mainly in the peasantry and certain middle-class groups. From the beginning it was considered to be basically a peasant movement: a rising against a conception of communist doctrine that damned everything the religious and patriotic peasants held sacred. As case studies consistently show, the big and middle-sized farms provided the main rural backing. ${ }^{42}$ The conservative Coalition party's strong support for the movement certainly resulted at least in part from the attitude of the large farmers. Among the Agrarians, however, small farmers appear not to have become involved..$^{43}$ Ideological features point in the same direction. In defending 'old values' $^{\prime 44}$ the movement was more conservative than most other fascist groups. Characteristically, the archbishop publicly adopted a favourable attitude to the movement in its initial phase. The absence of anti-capitalist demands in its proclamations, too, is rather exceptional. Although the movement was based on a peasant Weltanschauung that was alien to capitalism, it did not focus on the workings or threats of the capitalist system; rather, it stressed almost solely the manifestations of capitalism in class struggle. The Lapua movement felt that its main task was the continuation of the 'war for freedom' against the Communists, Social Democrats, and even the Russians. Its rhetoric repeated the most extreme images of 1918 White propaganda, ${ }^{45}$ capped by its two main symbolic figures, Svinhufvud and Mannerheim, the two most prominent White leaders of 1918.

Moreover, although the movement was supported in rural areas nationwide, it had two clear-cut regional strongholds, and these were not small-farmer regions. It was in the southern Ostrobothnian commune of Lapua that the antiCommunist riots took place in 1929. In this province peasantist moral indignation, springing from threats to a way of life, reappeared forcefully. As stated above, there was a marked contrast between the way of life here and in other

\footnotetext{
41 Upton 1968, pp. 209-10; Siltala 1985, pp. 143, 187-97.

42 E.g., Siltala 1984, pp. 22-4; Nieminen 1981, pp. 159-64.

43 Only in the county of Viipuri was there distinct small-farmer Agrarian support for the movement. But there the reaction was both weaker and less extreme than in Ostrobothnia and the south-west. See Siltala 1984, pp. 23-6.

44 Hyvämäki 1977, p. 134.

45 Siltala 1985, pp. 443-9, 455-69.
} 
regions. The provincial character of various revivalist and xenophobic manifestations of the movement is known: it was as if Ostrobothnia wanted to make it clear that when Lapua speaks, all of Finland must listen. ${ }^{46}$ The second bastion of support was in the south-west, ${ }^{47}$ the most prosperous farming region.

The reasons why agrarian support came mainly from large- and mediumscale farmers can presumably be traced back to the abortive revolution. These groups had provided the backbone of the 'White peasant army'. Moreover, the movement's strongholds corresponded to the two regions where the farmers had been most involved in the war as enemies of the revolution or subject to its rule (see Table 10, p. 120). The completion of the 'war for freedom' was an essential part of the movement's ideology, and the Coalition and Agrarian parties had played a central part in the subsequent national integration. But apparently a third ingredient was needed as well: the Great Depression. This crisis did not merely affect farmers in general, but it also first hit large and middle-sized farms, which experienced a decline in forestry income as early as 1928. Soon grain prices declined, aggravating the problems and leading to a great number of compulsory auctions at the turn of the decade. ${ }^{48}$

There is also evidence that the grievances of the small farmers were not channelled through the Lapua movement during the Depression. This group was hit by economic malaise later than others, for the forest work on which they so heavily depended was not decisively reduced until the early 193os. Only subsequently were small farms sold at auction in large numbers. It was among these cultivators that the so-called Depression movements erupted in the winter of 1931, concentrated in regions where small farmers had, to a larger extent than elsewhere, cleared land for cultivation, gone into debt, and been forced to give up their farms. In contrast to the Lapua movement, some of these amorphous and dispersed eruptions had distinct anti-capitalist features. ${ }^{49} \mathrm{In}$ the 1933 elections various small parties linked with Depression movements won five seats in Parliament (Table 11). These movements had helped the Agrarian Union to dissociate itself from the Lapua movement, which consequently came more under the influence of the Coalition party..$^{50}$

Various middle-class groups in liberal professions, commerce, and administration also provided support for the Lapua movement. It is indicative that

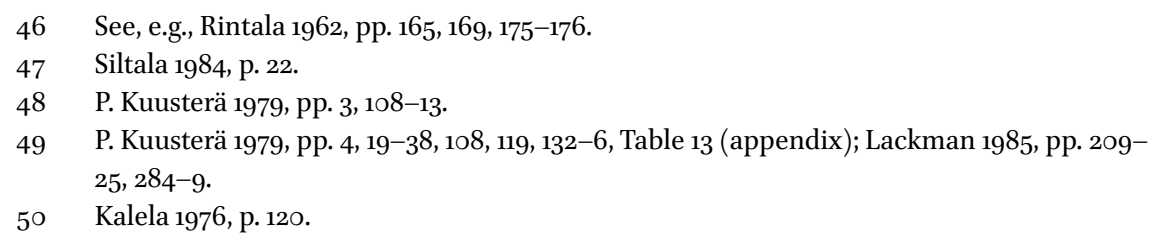


not only the Coalition party but also the more definitely middle-class Progress party went along with the Lapua movement in its initial phase. The role of the university-educated was very conspicuous. They were well represented among the organisers and supporters of the abductions, and they dominated the leading organs of the movement. A third of the members of the central council and of the district boards came from professional and governmental groups with higher education; together with people from the managerial and proprietary classes, they constituted a clear majority. It is no wonder, then, that the courts were reluctant to sentence the terrorists. ${ }^{51}$ Students and young academics, too, notably the Academic Karelia Society, the dominant organisation among Finnish-speaking students and the young educated class - were important supporters of the Lapua movement. ${ }^{52}$

The attitude of the educated middle classes differed from that of the peasants in one important respect, however. Rural support was based on a deep anti-communism, which was exacerbated by the Depression, and it declined soon after the elimination of the Communists from public life. But after mass support waned - and with Hitler's rise to power - fascism continued to attract the educated middle classes. In this, the permanent quest for national integration appears pivotal. The recovery of national integrity, lost in 1918, had been sought by the AKs throughout the 1920s. The Lapua movement seemed to provide an opportunity to restore solidarity between the people and the national educated class. Correspondingly, the new party, the People's Patriotic Movement (Isänmaallinen kansanliike, or IKL), which considered itself to be the heir of the Lapua movement, had a strong academic hue in its upper echelons. Its ideology, moreover, was more overtly fascist than that of the Lapua movement, with minor direct borrowings from German and Italian fascism. ${ }^{53}$

As I have described it, the Lapua movement was related mainly to the state and the various social classes, which are of the greatest relevance when assessing the role of fascism in Finnish state-making and when comparing it to fascist phenomena in other countries. The crucial problem is the relation of the fascist movement to authoritarian or conservative forces, or, in slightly different

$5^{1} \quad$ Siltala 1984, pp. 22, 30; Siltala 1985, pp. 403-19; Alapuro 1973a, p. 223.

$5^{2} \quad$ Alapuro 1973b, pp. 128-9.

53 Alapuro 1973a, pp. 53-4, 125-36, 144-6; Rintala 1963, pp. 308-10; Heinonen 198o, pp. 693-4. 
terms, the role of the dominant classes in the mass movement. Commonly, the former exploited the latter, but the two are generally more or less distinct. Fascism was not conservatism so much as 'an attempt to make reaction and conservatism popular and plebeian', as Barrington Moore puts it. ${ }^{54}$ Or, in Reinhard Kühnl's words: 'In order for the coup d'état to have a chance to materialize, a supply, i.e., a fascist mass movement created by socio-economic crisis, must be met by a corresponding demand, i.e., the hope by the ruling class for a fascist power system' ${ }^{55}$ Kühnl's remark brings to mind Germany in particular, where the dominant classes came to look on fascism as a potentially valuable ally against the workers only after it had proved its strength, its right to be taken seriously.

In characterisations of this kind, the relative autonomy of the fascist mass movement is stressed. Its specific character may be seen in its ideology, which to some extent differed from the ideology of the dominant classes, even if the two often had common roots. ${ }^{56}$ It is also known that the fascist movements drew their main support from the middle classes and, in the countryside, from the small farmers - that is, from outside both the working-class parties and the traditional conservative parties.

What was the relation between the mass movement and the dominant classes in Finland? Although it was supported by middle-sized farmers and to some extent by the middle classes, the Lapua movement was from the very beginning also a movement of the conservatives, including the large farmers. As time passed, the conservative or reactionary character of the movement became increasingly evident. And what is more, the small farmers, the backbone of rural fascism in a number of other countries, remained outside the movement, expressing their dissatisfactions through other channels.

It is characteristic of the phenomenon that the Lapua movement was not a political party and that its leadership remained vague. Rather, it was a loosely organised pressure group or faction within several parties, notably the Coalition party and, to a lesser extent, the Agrarian Union. The Swedish People's party, too, gave the movement considerable support. Differences in the attitudes of the bourgeois parties began to crystallise only in the course of time: in the initial stages acceptance and even enthusiasm were widespread, though not universal, in all of them. Finnish fascism assumed a more distinct middleclass character only after mass support had petered out. The I KL bore the stamp

54 Moore 1966, p. 447.

55 Kühnl 1971, p. 103.

$5^{6} \quad$ Kühnl 1971, pp. 84-99; Moore 1966, 448-52. 
of the middle class, even if most of its adherents were former conservative voters. ${ }^{57}$ It also cooperated closely with the Coalition party up until the latter half of the 1930s.

What all this means is that in Finland, the relation between the fascist mass movement and the dominant classes was intimate from the very beginning. In its initial stage the Lapua movement was basically a general bourgeois reaction, though whether the mass movement arose spontaneously or was instigated by the dominant classes has been a subject of controversy. ${ }^{58}$ In the present perspective this question is not very relevant. The rise of the mass movement and the dominant classes' need for it were closely interconnected. The view of fascism as an agent called in to restore order only after it had proved its right to be taken seriously is not accurate in the Finnish case.

The connection seems to result from the character of the bourgeois front after the abortive revolution. As stated above, a united, nationalistic political culture existed, despite different national integration strategies. On the one hand this unity implied that there was considerable rightist potential in the bourgeois groups, all prone to react strongly to any threat against central national values. On the other hand, noting the strength and cultural unity of the bourgeois front is merely another way of indicating the absence of strong and salient reactionary forces in the bourgeoisie. In this situation, the emergence of an extensive fascist-type movement was easy, but it was therefore also destined to remain rather shallow, without a distinct profile of its own. It was, as has been said, 'the political extension of the civil guard ethos.59

In the end, no German- or Italian-type basis for a fascist takeover existed in Finland. In Germany and Italy, World War I had left the capitalists in control of the economy but at the same time accorded the working class a share of the political power and the right to organise and agitate for its own ends. In Finland rather the contrary was true: the working class had been defeated in 1918. When the Lapua movement eliminated the Communists in 1930, moreover, it thereby emasculated the trade union movement, which in the 1920 s had been fairly active. ${ }^{60}$ During the Depression workers' wages fell in Finland more than in Scandinavia, mainly because of trade union weakness: in the mid-193os, wages

57 In the general elections of 1933, the Coalition party and the IKL formed party alliances in almost all constituencies. Small towns were the most typical IKL strongholds (Djupsund and Karvonen 1984, pp. 51-4, 79-81).

$5^{8}$ See Wahlbäck 1967, pp. 107-10.

59 Siltala 1985 , p. 497.

6o The final blow against the trade union movement was preceded by a deep internal crisis in 1929, resulting from conflict between the Communists and the Social Democrats. See Kettunen 1979, pp. 309-11, 453-73. 
were generally less than half what they were in Sweden or England. ${ }^{61}$ Thus the interests of industry were very well taken care of by the existing political and economic system. The export industry in particular maintained its competitiveness, escaping the Depression comparatively unscathed, and economic growth in the inter-war period was very rapid. ${ }^{62}$ The conflicts in the economy, with the accompanying turmoil in the labour market and in society as a whole, never polarised the population in Finland as they did in Germany, where the dominant classes felt even more urgently the need to find an agent to restore order.

The stand of the peasantry was at least as important. Although peasants responded enthusiastically to the Lapua movement, they soon began to dissociate themselves from it. For one thing, the early proscription of the Communists satisfied most of the peasants' demands, and the Depression movements caused the Agrarians to withdraw their support. In 1932, too, the Depression began to abate. Finally, the Agrarian Union showed no sympathy for the movement's agitation against the Social Democrats, who, in the centrist view, were to be reintegrated in the national body and who in the 192os had confirmed their non-radical orientation. In this respect the Finnish Social Democrats differed greatly from certain brother parties, which responded to the rise of fascism with a revolutionary counter-mobilisation. ${ }^{63}$ Indeed, the exclusion of the Social Democrats would have unbalanced the political system to the advantage of the right, a development that would have been unacceptable to the centrists.

The solid position of the independent peasantry and their party in the state and society was largely responsible for this pattern of events. ${ }^{64}$ To a very large extent, both the rise and fall of the Lapua movement were determined by the peasantry - as the failure of the movement's leadership to mobilise the peasant rank and file of the civil guards during the Mäntsälä revolt indicates: the peasantry, influenced by the preceding Agrarian propaganda, obeyed Svinhufvud's exhortation to stay at home. The fear generated by the attempted revolution, combined with the proximity of the consolidating Soviet state, laid the ground for an extensive fascist-type movement, but the weak position of the working class, the strong role of the executive, a political system that had been firmly anchored in social groups since 1906, and, ultimately, the Scandinavian social structure placed constraints on it.

\footnotetext{
$61 \quad$ Knoellinger 196o, p. 85.

$62 \quad$ Pollard 1981, p. 289; Raumolin 1981, pp. 3-5.

63 Linz 1978, pp. 162-7, 178; Simon 1978, pp. 104-6.

64 Cf. Ahti 1984b, pp. 35-7.
} 